\title{
Biological, Toxicological Potency and Field Persistence of New Insecticides against Spodoptera littoralis (Boisduval)
}

\author{
Madeha E.H., El-Dewy 1
}

\begin{abstract}
Conventional insecticides exhibited negative effects on environment components and natural enemies. The tested noval insecticides, viz pyridalyl, emamectin-benzoate and indoxacarb compared to chlorfluazuron were evaluated against $2^{\text {nd }}$ and $4^{\text {th }}$ larval instar of Spodoptera littoralis (Boisd.) laboratory strain and their latent effects on some biological aspects were studied. Also, field persistence residues of these tested compounds against field strain of this pest were estimated via determination of $\mathbf{L t}_{50}$ values. On basis of $\mathrm{LC}_{50}$ values, emamectin benzoate was the most effective compound, followed by indoxacarb and chlorfluazuron, while pyridelyl was the least toxic one, where the $\mathrm{LC}_{50}$ values were $0.539,5.218,29.83$ and 39.32 $\mathrm{mg}$ a.i./L after $48 \mathrm{~h}$, while the $L_{C_{50}}$ values were 0.278 , 2.732, 7.198 and $27.3 \mathrm{mg}$ a.i./L after $72 \mathrm{~h}$ from exposure, respectively against $4^{\text {th }}$ larval instar of $S$. littoralis. From these results, the toxicity of the tested compounds increased with the increasing in the exposure time and decreased by increasing the larval instars. The latent effects of the tested compounds according to sublethal concentrations against $4^{\text {th }}$ instar larvae of laboratory strain were significantly decreased in pupal duration, pupal weight, percentage of normal pupae, adult emergence, fecundity, fertility and adult longevity compared to the control, while these compounds increased significantly larval duration and malformed pupae. Based on the semi-field application, pyridalyl and emamectinbenzoate proved to be the most effective in initial and residual activity causing 100 and $54 \%$ mortality for pyridalyl and 100 and $42.13 \%$ for emamectin-benzoate, respectively, while indoxacarb was the least effective. Also, pyridalyl show significant, superior persistence residual activity against $4^{\text {th }}$ larval instar of the field strain with $\mathbf{L t}_{50}$ valued 7.74 days, emamectin-benzoate and chlorfluazuron come in second order, with $\mathbf{L t}_{50} 5.59$ and 5.56 days, respectively, indoxacarb showed the shortest (1.4 days). From the results, pyridalyl and emamectin-benzoate could be used into Integrated Pest Management against Spodoptera littoralis under field conditions.
\end{abstract}

\section{INTRODUCTION}

The Egyptian cotton leafworm, Spodoptera littoralis (Boisd). is a highly polyphagous insect pest, it is still considered as one of the most destructive insect pests in cotton growing areas not only in Egypt but also in Africa, Mediterranean Europe and several parts of Asia (Smagghe and Degheele, 1997 and Azab et al., 2001). The extensive use of insecticides to control this pest larvae has led to the development of multiple insecticide resistance, environmental pollution and negative effects on non-target organisms (Tabashink et al., 1987 and Frank et al., 1990). Therefore, there is a great need to research alternative control agents with new mode of action, safe to untarget organisms and environment components and compatible with integrated pest management practices. Among the most promising alternative to conventional insecticides are insect growth regulators and noval insecticides including oxadiazines, avermectins and pyridalyl which characterized with their new and/or unique modes of action, they have the potential for crop protection against economic pests and low toxicity to environment components and natural enemies (Foster et al., 2003; Michaud and Grant, 2003 and Sakamoto et al., 2005). Emamectin-benzoate is a noval semi-synthetic derivative of natural product abamectin in avermectin family. Abamectins (Avermectin B1) is a fermentation product from the soil microorganisms, Streptomyces avermactilis (Burg et al., 1979). This materials act by interfering with the action of gamma aminobutyric acid (GABA), it blocks post-synaptic potentials of neuromuscular junctures, leading to paralysis, also inhibit pheromones production and inhibit feeding (Fritz et al, 1979;p Pienkowski and Mehring, 1983 and Writht, 1984). Abamectin also is more environmentally acceptable because it binds to soil, does not bioaccumulate and degrades rapidly (Lasota and Dybas, 1991), this epi-methyl amino derivative is very effective against a broad spectrum of Lepidoptera pests with good field efficacy and lack of cross-resistance with other commercially used pesticides (Mrozik, 1994 and White et al., 1997). Pyridalyl is a noval insecticide exerts excellent control against Lepidoptera and Thysanopetera pests on cotton, vegetable and fruits, pyridalyl is expected to be an ideal pest control compound for use in Insect Resistance Management (IRM) (Sakamato et al., 1995 and Sakamoto and Umedo, 2003). The insect development inhibitors (IDI), which inhibits or prevents normal metamorphosis of immature stages to the adults stages, these compounds tends to be selective and generally less toxic to notarget organism than conventional insecticides (Nicholas et al., 1999). Generally, many IGR compounds have shown high potentiality against lepidopterous insects (El-Deeb et al., 1991; Fisk and

\footnotetext{
${ }^{1}$ Plant Protection Res. Inst. Agric. Res. Cent., Giza, Egypt

Received July 31, 2013, Accepted September 18,2013
} 
Wright, 1992; Rao et al., 1994; Pineda et al., 2007; Sammour et al., 2008 and Zidan et al., 2013).

Therefore, this study aimed to evaluate the toxicity of three noval alternative control agents (pyridalyl, emamectin-benzoate and indoxacarb) compared to chlorfluazuron against larval stages of Spodoptera littoralis (Boisd.), the study also included the sublethal effects of the previous compounds on biological aspects of this pest and determined the residues persistence period $\left(\mathrm{Lt}_{50}\right)$ under semi-field conditions.

\section{MATERIALS AND METHODS}

\section{Insecticides used:}

- Benzoylphenyl urea insecticide, chlorfluazuron (Atapron, EC 5\%), obtained from Sumitomo Chemical Co., Ltd. and was applied at $100 \mathrm{mg}$ a.i./L.

- Oxadiazine insecticide, indoxacarb (Steward, EC $15 \%$ ), provided from DU Pont Co., and was applied at $39 \mathrm{mg}$ a.i./L.

- The noval insecticide, pyridalyl (Pleo, EC 50\%), supplied from Sumitomo Chemical Co., and was applied at $250 \mathrm{mg}$ a.i./L.

- Avermectin derivative insecticide, emamectinbenzoate (Proclaim, SG 5\%), obtained from Syngenta Co. and was applied at $15 \mathrm{mg}$ a.i./L.

\section{Insect rearing:}

2.2.a.The laboratory strain of Spodoptera littoralis (Boisduval) was reared in the laboratory of Sakha Agricultural Research Station on castor bean leaves. The egg-masses were collected daily and they were hatched on the oleander leaves. The larvae were transferred to fresh castor oil leaves. The colony was kept at a temperature of $25 \pm 2{ }^{\circ} \mathrm{C}$ and $\mathrm{RH}$ of $65 \pm$ $5 \%$ (El-Defrawi et al., 1964), the newly moulted $2^{\overline{n d}}$ and $4^{\text {th }}$ instar larvae were used for this study.

2.2.b.The field strain was obtained by the collection of the egg-masses from cotton plants at the Sakha Agricultural Research Station in early June 2013 before the start of chemical control programme. The egg-masses were transferred to the laboratory then the new hatches were reared according to the previous rearing method.

\subsection{Toxicity studies:}

Toxicity of chlorfluazuron, indoxacarb, pyridalyl and emamectin-benzoate against $2^{\text {nd }}$ and $4^{\text {th }}$ larval instar of laboratory strain were evaluated. To assess the insecticidal activity of the tested compound, a series of aqueous concentrations for each compounds was prepared using the commercial formulations. The leaf dipping technique was adopted according to Abo ElGhar et al. (1994) where the freshly castor bean leaves were allowed to dry under laboratory conditions before being offer to $S$. littoralis larvae. Hundred larvae distributed in ten replicates (10 larvae/replicate) were used for each concentration. Also, larvae were fed on leaves immersed in only water as a control. Newly moulted $2^{\text {nd }}$ and $4^{\text {th }}$ larval instar were fed on the treated leaves in a glass jar covered with muslin for $24 \mathrm{~h}$. for indoxacarb, pyridalyl and emamectin-benzoate and for $48 \mathrm{~h}$ for chlorfluazuron after that the treated leaves were replaced by another untreated ones. Mortality percentages were recorded after 24, 48 and $72 \mathrm{~h}$ of treatment. Mortality percentages were corrected according to Abbott equation (Abbott's, 1925). The $\mathrm{LC}_{25}, \mathrm{LC}_{50}$ and slope values of the tested compounds were calculated using Finney's equation (1971), through software computer program.

\subsection{Biological studies:}

Castor bean leaves were soaked in $\mathrm{LC}_{25}$ concentration for each insecticide, which calculated after $48 \mathrm{~h}$ and used for feeding the newly $4^{\text {th }}$ larval instar. Two hundred larvae were used for each insecticide, the larvae were placed in a glass jar and provided with the treated leaves after $24 \mathrm{~h}$ for indoxacarb, pyridalyl and emamectinbenzoate and $48 \mathrm{~h}$ for chlorfluazuron. Survived larvae were transferred to jars containing fresh untreated leaves and observed daily to determine larval duration, pupal duration, pupal weight, percentages of normal pupae, deformed pupae and adult emergence. Two females and one male of the resulted adults were placed together, in wood box to maximize successful mating, they provided with a piece of cotton soaked in $10 \%$ sugar solution as source of food for each of the four compounds and the control. Then the adult longevity was determined (from adult emergence until adult death for male and female), fecundity (no. of eggs/female), fertility (percentage of eggs hatchability) and fecundity percentage was calculated according to Crystal and Lachance (1963) as follows:

$\%$ Fecundity $=\frac{\text { No.eggs } / \text { treated female }}{\text { No.eggs } / \text { untreated female }} \times 100$

All biological aspects were analyzed using one-way ANOVA by SPSS 13.0 (SPSS, 2004). Duncan's Multiple Range Test (DMRT) was used to determine the probability level to compare the differences among some parameter means $(\mathrm{P}<0.05)$ by Costat system for Windows, Version 6.311, Berkeley, CA, USA, Costat program (2006).

\subsection{Field experiments:}

Application of the tested insecticides were conducted at Sakha Agricultural Research Station farm, where an area of $2100 \mathrm{~m}^{2}$ was selected to be sown on $4^{\text {th }}$ April, 2013 with cotton seed var. Giza 86, received all good recommended agricultural practices without any 
insecticidal treatments. This area was divided into plots each of $42 \mathrm{~m}^{2}$. Five treatments, the four tested insecticides and the check were designed in this area. Four plots (replications) were arranged in a randomized complete block design. Application of tested insecticides was done on $26^{\text {th }}$ of June, 2013 under field conditions. Irrigation water was used in diluting of the tested insecticides at their field recommended rates/200 liters per feddan. Knapsack sprayer (CP3) equipped with one nozzle was used. Unplanted belts ( $3 \mathrm{~m}$ width) were left as barriers between plots to avoid contamination with drifts.

\section{5.a. Semi-field experiments:}

Chlorfluazuron, indoxacarb, pyridalyl and emamectin-benzoate were sprayed at their recommended rates/200 liters per feddan. Samples of treated cotton leaves were collected randomly from each treatment immediately after one $\mathrm{h}$ from spray (zero time) and then 3, 6, 9 and 12 days post spray and transferred directly to the laboratory for feeding $4^{\text {th }}$ larval instar (field strain) of $S$. littoralis by treated leaves with indoxacarb, pyridalyl and emamectin benzoate, (100 larvae/treatment/interval) for one day of each interval. The survivor larvae were fed for another two days on untreated leaves. For chlorfluazuron larvae were fed on treated leaves two days and one day on untreated leaves. Cumulative mortalities were calculated at the end of each interval (three days) and corrected according to Abbott's formula (1925).

The cumulative mortalities of the first intervals (samples collected after spraying directly) was considered as initial kill, while the total mean of the cumulative mortality of the other intervals $(3,6,9$ and 12 days from spraying) were considered as residual effects.

\section{RESULTS AND DISCUSSION}

Susceptibility of $2^{\text {nd }}$ and $4^{\text {th }}$ larval instars of Spodoptera littoralis, laboratory strain to three noval insecticides, viz. indoxacarb, pyridalyl and emamectinbenzoate compared with chlorfluazuron were studied and their latent effects of the previous insecticides against $4^{\text {th }}$ larval instar of $S$. littoralis were evaluated according to sublethal effect after $48 \mathrm{~h}$ from exposure on some biological aspects. Also, semi-field application was determined to study persistence of chlorfluazuron, indoxacarb, pyridalyl and emamectin-benzoate residues against $4^{\text {th }}$ larvae instar at field strain of this pest via determination of $\mathrm{Lt}_{50}$ when the larvae were fed on treated leaves after different intervals from spray of these insecticides.

\section{1.Toxicity of some insecticides against $2^{\text {nd }}$ and $4^{\text {th }}$ larval instars of Spodoptera littoralis:}

Toxicity of three noval insecticides, indoxacarb, pyridalyl and emamectin-benzoate compared with chlorfluzuron against $2^{\text {nd }}$ and 4thh larval instar of $S$. littoralis, laboratory strain were presented in Tables (1 and 2).

The results in Table (1) showed that emamectinbenzoate proved to be the most effective compound against $2^{\text {nd }}$ larval instar of different exposure time, where LC $_{50}$ values were $0.623,0.19$ and $0.111 \mathrm{mg}$ a.i./L after 24,48 and $72 \mathrm{~h}$ of exposure. It is important to note that there was a negative relationship between the time elapsed post treatment and $\mathrm{LC}_{50}$ values to reach 0.356 , 0.863 and $7.98 \mathrm{mg}$ a.i./L after $48 \mathrm{~h}$ and $0.117,0.348$ and $4.45 \mathrm{mg}$ a.i./L after $72 \mathrm{~h}$ for indoxacarb, chlorfluazuron and pyridalyl, respectively. According to toxicity index at $\mathrm{LC}_{50}$ values after $72 \mathrm{~h}$ to chlorfluazuron, where it is specifically insecticide against $S$. littoralis larvae, the results in Table (1) showed that emamectin-benzoate was $313.5 \%$ as toxic as chlorfluazuron, while pyridalyl was the least effective recording $7.82 \%$ as toxic as chlorfluazuron. The same trend was noticed with all tested insecticides against $4^{\text {th }}$ larval instar of $S$. littoralis. Also, the results in Table (2) cleared that, the descending order of larvicidal activity against fourth larval instar were emamectin-benzoate, indoxacarb, chlorfluazuron and pyridalyl, where the $\mathrm{LC}_{50}$ values were $0.539,5.218$, 29.83 and $39.32 \mathrm{mg}$ a.i./L after $48 \mathrm{~h}$, while, they recorded $0.278,2.732,7.198$ and $27.31 \mathrm{mg}$ a.i./L after $72 \mathrm{~h}$, respectively. From these data, it was clear that the toxicity of the tested compounds against two larval instars of $S$. littoralis were increased with the increasing of the exposure time and decreased by increasing the larval instars. The present results are confirmed with the results of Shigeru et al. (2004), Isayama et al., (2005) and Ahmed et al., (2006) who found that emamectin-benzoate proved to be more efficient than spinosad and indoxacarb against $S$. litura larvae, also Abdel-Rahim et al. (2009), Ezz El-Din et al., (2009) and Abdu-Allah (2010) reported that emamectin-benzoate was the most effective compound against $4^{\text {th }}$ instar larvae of $S$. littoralis.

\section{2. Sublethal effect of the tested insecticides on some biological aspects of Spodoptera littoralis:}

The main biological aspects of $S$. littoralis, laboratory strain after feeding the $4^{\text {th }}$ larvae for $24 \mathrm{~h}$ for indoxacarb, pyridalyl and emamectin-benzoate and $48 \mathrm{~h}$ for chlorfluazuron on castor bean leaves treated at their $\mathrm{LC}_{25}$ values were shown in Tabel (3 and 4).

The results in Table (3) indicated that indoxacarb significantly prolonged the larval duration (24.5 days) comparing to control treatment (14.0 days), followed by emamectin-benzoate (15.5 days) and pyridalyl (14.5 
Table 1. Susceptibility of Spodoptera littoralis, laboratory strain at $2^{\text {nd }}$ larval instar to chlorfluazuron, indoxacarb, pyridalyl and emamectin-benzoate

\begin{tabular}{|c|c|c|c|c|c|}
\hline Compound & $\begin{array}{c}\text { Conc. } \\
\text { mg a.i./L }\end{array}$ & After 24 h & After 48 h & After 72 h & $\begin{array}{l}\text { Toxicity index of } \\
\text { LC }_{50} \text { after } 72 \mathrm{~h}\end{array}$ \\
\hline \multirow{3}{*}{ Chlorfluazuron } & $\mathrm{LC}_{25}$ & 0 & 0.178 & 0.061 & \multirow{4}{*}{100} \\
\hline & $\mathrm{LC}_{50}$ & 0 & 0.863 & 0.348 & \\
\hline & Slone + SE & & $(0.65-1.30)$ & $(0.272-0.450)$ & \\
\hline \multirow{4}{*}{ Indoxacarb } & $\mathrm{LC}_{25}$ & 0 & $0.98 \pm 0.434$ & $0.8789 \pm 0.123$ & \\
\hline & $\mathrm{LC}_{25}$ & & 0.091 & 0.04 & \multirow{3}{*}{297.44} \\
\hline & $\mathrm{LC}_{50}$ & 0 & $\begin{array}{c}0.356 \\
(0.215-0.495)\end{array}$ & $\begin{array}{c}0.117 \\
(0.092-0.146)\end{array}$ & \\
\hline & Slope \pm SE & 0 & $1.55 \pm 0.165$ & $0.96 \pm 0.204$ & \\
\hline \multirow{3}{*}{ Pyridalyl } & $\mathrm{LC}_{25}$ & 7.93 & 2.13 & 1.63 & \multirow{3}{*}{7.82} \\
\hline & $\mathrm{LC}_{50}$ & $\begin{array}{c}28.09 \\
(22.88-33.53)\end{array}$ & $\begin{array}{c}7.98 \\
(308-1354)\end{array}$ & $\begin{array}{c}4.45 \\
(21-642)\end{array}$ & \\
\hline & Slope \pm SE & $1.228 \pm 0.139$ & $1.52 \pm 0.189$ & $1.67 \pm 0.221$ & \\
\hline \multirow{4}{*}{$\begin{array}{l}\text { Emamectin- } \\
\text { benzoate }\end{array}$} & $\mathrm{LC}_{25}$ & 0.332 & 0.113 & 0.053 & \multirow{4}{*}{313.5} \\
\hline & I $C_{-}$ & 0.623 & 0.19 & 0.111 & \\
\hline & $\mathrm{LC}_{50}$ & $(0.346-0.957)$ & $(0.124-0.258)$ & $(0.078-0.158)$ & \\
\hline & Slope \pm SE & $2.47 \pm 1.23$ & $2.96+0.31$ & $2.03+0.19$ & \\
\hline
\end{tabular}

Table 2. Susceptibility of Spodoptera littoralis, laboratory strain at $4^{\text {th }}$ larval instar to chlorfluazuron, indoxacarb, pyridalyl and emamectin-benzoate

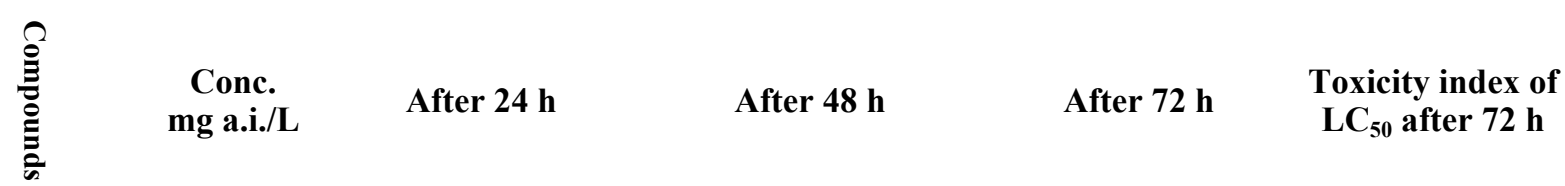

\begin{tabular}{|c|c|c|c|c|c|}
\hline \multirow{3}{*}{ Chlorfluazuron } & $\mathrm{LC}_{25}$ & 0 & 7.0 & 3.3 & \multirow{3}{*}{100} \\
\hline & $\mathrm{LC}_{50}$ & 0 & $\begin{array}{c}29.83 \\
(17.569-44.308)\end{array}$ & $\begin{array}{c}7.198 \\
(6.283-8.259)\end{array}$ & \\
\hline & $\overline{\text { Slope + SE }}$ & 0 & $1.52+0.681$ & $1.9+0.32$ & \\
\hline \multirow{3}{*}{ Indoxacarb } & $\mathrm{LC}_{25}$ & 0 & 2.62 & $1 . \overline{352}$ & \multirow{3}{*}{263.47} \\
\hline & $\mathrm{LC}_{50}$ & 0 & $\begin{array}{c}5.218 \\
(4.208-8.07)\end{array}$ & $\begin{array}{c}2.732 \\
(2.476-3.12)\end{array}$ & \\
\hline & Slope \pm SE & 0 & $1.62 \pm 0.393$ & $1.862 \pm 0.284$ & \\
\hline \multirow{3}{*}{ Pyridalyl } & $\mathrm{LC}_{25}$ & 28.11 & $1 \overline{4} .5$ & 13.02 & \multirow{3}{*}{26.36} \\
\hline & $\mathrm{LC}_{50}$ & $\begin{array}{c}76.92 \\
(53.43+94.28)\end{array}$ & $\begin{array}{c}39.32 \\
(18.1+53.34)\end{array}$ & $\begin{array}{c}27.31 \\
(7.48+40.19)\end{array}$ & \\
\hline & Slope \pm SE & $1.59 \pm 0.415$ & $1.52 \pm 0.395$ & $2.33 \pm 0.682$ & \\
\hline \multirow[b]{2}{*}{$\begin{array}{l}\text { Emamectin- } \\
\text { benzoate }\end{array}$} & $\mathrm{LC}_{25}$ & & 0.177 & 0.124 & \multirow[b]{2}{*}{2589.2} \\
\hline & $\frac{\mathrm{LC}_{50}}{\text { Slope }+\mathrm{SE}}$ & & $\begin{array}{c}0.539 \\
(0.42+0.721) \\
1.392+0.197\end{array}$ & $\begin{array}{c}0.278 \\
(0.225+0.336) \\
1.925+0.22\end{array}$ & \\
\hline \multicolumn{3}{|c|}{$\begin{array}{l}\text { days), the same direction was observed on pupal } \\
\text { duration and pupal weight, where indoxacarb was the } \\
\text { highest effective recording ( } 8.5 \text { days and } 306 \mathrm{mg}) \\
\text { comparing to control ( } 12 \text { days and } 346 \mathrm{mg}) \text {, while } \\
\text { pyridalyl was the least effective ( } 9 \text { days and } 331 \mathrm{mg} \text { ) on } \\
\text { pupal duration and pupal weight, respectively. With } \\
\text { respect to the latent effects, percentages of normal } \\
\text { pupae, deformed pupae and adult emergence, the data in } \\
\text { Table (3) indicated that indoxacarb was more effective }\end{array}$} & \multicolumn{3}{|c|}{$\begin{array}{l}\text { giving }(66 \%, 14.29 \text { and } 65.85 \%) \text { compared to control } \\
(97,2.84 \text { and } 97.66 \%) \text { to percentages of normal pupae, } \\
\text { deformed pupae and adult emergence, respectively, } \\
\text { followed by pyridalyl (19.0, } 0.0 \text { and } 94.74 \%) \text {, while } \\
\text { emamectin-benzoate was the least effective giving } \\
(80.0,6.25 \text {, and } 96.97 \%) \text {, respectively. The previous } \\
\text { data in Table (3) showed that indoxacarb was more } \\
\text { effect on all biological aspects which was remarkable } \\
\text { antifeeding activity on } S \text {. littoralis, therefore, it caused }\end{array}$} \\
\hline
\end{tabular}


disturbance in the physiological functions, also the present results clearly showed that sublethal concentration of chlorfluazuron caused $100 \%$ mortality after two days from feeding on treated leaves, so chlorfluazuron nullified pupation stage from treated larvae.

The obtained results were in accordance with those of Aioub et al. (2002) and El-Naggar and El-Dewy (2012). They found that lufenuron caused nullifying in adult emergence from treated larvae, while the present results were in contrary with those of Emam and Degheele (1993) and Sammour et al. (2008). They found that the fecundity of the $S$. littoralisi adults resulted from the $5^{\text {th }}$ instar treated with chlorfluazuron and lufenuron treatments decreased to a very low percentage ranged between (33.3 to $53.4 \%$ ) and they added that $S$. littoralis egg hatchability was also significantly reduced, it ranged between (44.5 to $61.7 \%$ ) for chlorfluazuron and (59.7 to $73 \%$ ) for lufenuron compared to $(94.7 \%)$ for control.

Table 3. Some biological aspects for survived $4^{\text {th }}$ larval instar of Spodoptera littoralis, laboratory strain which treated by $\mathrm{LC}_{25}$ value of chlorfluazuron, indoxacarb, pyridalyl and emamectin-benzoate

\begin{tabular}{|c|c|c|c|c|c|c|}
\hline Compound & $\begin{array}{c}\text { Larval duration } \\
\text { days } \pm \text { SE }\end{array}$ & $\begin{array}{l}\text { Pupal duration } \\
\quad \text { days } \pm S E\end{array}$ & $\begin{array}{c}\text { Pupal weight } \\
\text { mg } \pm \text { SE }\end{array}$ & $\begin{array}{c}\text { Normal } \\
\text { pupae } \\
\% \pm \mathrm{SE}\end{array}$ & $\begin{array}{c}\text { Deformed } \\
\text { pupae } \\
\% \pm \text { SE }\end{array}$ & $\begin{array}{c}\text { Adult emergence } \\
\% \pm \mathrm{SE}\end{array}$ \\
\hline \multirow{3}{*}{ Indoxacarb } & 24.5 & 8.5 & 306 & 66.04 & 14.29 & 65.85 \\
\hline & \pm & \pm & \pm & \pm & \pm & \pm \\
\hline & $.0 .66 \mathrm{a}$ & $0.236 \mathrm{c}$ & $0.05 \mathrm{~d}$ & 2.82 & 0.372 & 0.4 \\
\hline \multirow[t]{3}{*}{ Pyridalyl } & 14.5 & 9 & 331 & 19 & 0.0 & 94.74 \\
\hline & \pm & \pm & \pm & \pm & & \pm \\
\hline & $0.282 \mathrm{bc}$ & $0.801 \mathrm{c}$ & $0.038 \mathrm{c}$ & 0.94 & & $0 . \overline{348}$ \\
\hline \multirow[t]{3}{*}{ Emamectin-benzoate } & 15.5 & 10.5 & 373 & 80.0 & 6.25 & 96.97 \\
\hline & \pm & \pm & \pm & \pm & \pm & \pm \\
\hline & $0 . \overline{33} \mathrm{~b}$ & $0 . \overline{62} \mathrm{~b}$ & $0.057 \mathrm{a}$ & $2 . \overline{3} 57$ & $0 . \overline{12}$ & $0 . \overline{4} 54$ \\
\hline \multirow[t]{3}{*}{ Control } & 14.02 & 12.0 & 346 & 97 & 2.84 & 97.66 \\
\hline & \pm & \pm & \pm & \pm & \pm & \pm \\
\hline & $0.707 \mathrm{c}$ & $471 \mathrm{a}$ & $0.08 \mathrm{~b}$ & 0.47 & $0 . \overline{065}$ & 0.47 \\
\hline
\end{tabular}

$\mathrm{SE}=$ Standard error

Means in the same column followed by the same letter are not significant different according to Duncan Multiple Range Test (1955).

Table 4. Fecundity, fertility and adult longevity for survived $4^{\text {th }}$ larval instar of Spodoptera littoralis, laboratory strain after feeding by $\mathrm{LC}_{25}$ value of chlorfluazuron, indoxacarb, pyridalyl and emamectin-benzoate

\begin{tabular}{|c|c|c|c|c|c|}
\hline \multirow{2}{*}{ Compound } & \multirow{2}{*}{$\begin{array}{c}\text { No. of eggs/female } \\
\pm \text { SE }\end{array}$} & \multirow{2}{*}{$\begin{array}{c}\text { Egg hatchability\% } \\
+\mathrm{SE}\end{array}$} & \multirow{2}{*}{$\begin{array}{c}\text { Fecundity \% } \\
\pm \text { SE }\end{array}$} & \multicolumn{2}{|c|}{ Adult longevity days $\pm \mathrm{SE}$} \\
\hline & & & & Male & Female \\
\hline \multirow{3}{*}{ Indoxacarb } & 484.29 & 58.42 & 28.38 & 4.36 & 6.92 \\
\hline & \pm & \pm & \pm & \pm & \pm \\
\hline & $10 . \overline{8} 4 \mathrm{~d}$ & $2 . \overline{8} 3$ & $0 . \overline{4} 15$ & $0.2 \overline{3} 8 \mathrm{c}$ & $0.4 \overline{3} 4 \mathrm{~d}$ \\
\hline \multirow{3}{*}{ Pyridalyl } & 1031.15 & 31.95 & 60.42 & 14.05 & 15.13 \\
\hline & \pm & \pm & \pm & \pm & \pm \\
\hline & $5 . \overline{19} \mathrm{c}$ & $2 . \overline{8} 3$ & $0 . \overline{9} 4$ & $0 . \overline{71} \mathrm{a}$ & $0.2 \overline{9} 7 \mathrm{~b}$ \\
\hline \multirow{3}{*}{ Emamectin-benzoate } & 1330 & 49.31 & 77.98 & 11.97 & 13.67 \\
\hline & \pm & \pm & \pm & \pm & \pm \\
\hline & $4 . \overline{71} \mathrm{~b}$ & $2 . \overline{3} 6$ & $1 . \overline{7} 4$ & $0 . \overline{61} \mathrm{~b}$ & $0 . \overline{32} \mathrm{c}$ \\
\hline \multirow{3}{*}{ Control } & 1706.65 & 90.0 & \multirow{3}{*}{100} & 15.0 & 16.13 \\
\hline & \pm & \pm & & \pm & \pm \\
\hline & $7 . \overline{07} \mathrm{a}$ & 3.7 & & $0 . \overline{33} \mathrm{a}$ & $0 . \overline{19} \mathrm{a}$ \\
\hline
\end{tabular}

$\mathrm{SE}=$ Standard error

Means in the same column followed by the same letter are not significant different according to Duncan Multiple Range Test (1955) 
The same direction was observed in the data in Table (4) that showed indoxacarb was more effective in reducing the adult fecundity (No. of eggs/female) and \% fecundity giving (484.29 egg/female and 28.38\%), followed by pyridalyl (1031.15 egg/female and $60.42 \%)$ as compared to (1706.65 eggs/female and 100\%) for control, while emamectin-benzoate was low significant for the adult fecundity, as compared to control. Likewise, pyridalyl, emamectin-benzoate and indoxacarb reduced the adult fertility (percentage of eggs hatchability) where they giving $31.95,49.31$, and $58.42 \%$, respectively in comparison with control (90\%). Reduction in fecundity may be due to disfunction of maturation of an insect egg which depend on the materials that are synthesized by the ovary in suit which includes protein, lipids and carbohydrates all of which required for embryonic structure (Shaurub et al. 1998).

Data in Table (4) indicated that the tested insecticides reduced significantly the adult longevity of both males and females, where indoxacarb reduced with highly significant the adult longevity to average (4.36 and 6.92 days) followed by emamectin-benzoate (11.97 and 13.67 days), pyridalyl (14.05 and 15.13 days) as compared to control (15 and 16.13 days) for male and female longevity, respectively. The foregoing results are in agreement with the trend of results obtained by many investigators (El-Aw, 2003; Abdel-Rahim et al., 2009; Amer et al., 2012 and El-Naggar, 2013). They indicated that emamectin-benzoate was more effective against $4^{\text {th }}$ larval instar of $S$. littoralis than pyridalyl on the most biological aspects, these compounds decreased larval, pupal and adult durations, pupation $\%$, adult emergency $\%$, fecundity, fecundity $\%$ and fertility, while El-Zahi (2013) found that indoxacarb significantly produced the least percentage of normal pupae and deformed pupae (26.4 and $20.3 \%$ ) at zero time from spray, also, the author demonstrated that the pyridalyl and emamectin benzoate had the highest persistent negative effect on pupation causing (20.4 and 42\%) normal pupae, (12.9 and $10.3 \%$ ) deformed pupae and (26.7 and 55.2\%) normal adult, respectively.

\section{3. The field persistence of the tested compound residues:}

Semi-field application was determined to study initial, residual effect and persistence of chlorfluazuron, indoxacarb, pyridalyl and emamectin-benzoate residues against $4^{\text {th }}$ larval instar of $S$. littoralis, field strain via determination of $\mathrm{Lt}_{50}$ when the larvae were fed on treated leaves after (zero time, 3, 6, 9 and 12 days) from spray of these insecticides.
With regard to the initial effect (at zero time after spray), pyridalyl and emamectin-benzoate proved to be the most effective where they caused $100 \%$ accumulative mortalities after 3 days from feeding, when the larvae were fed on treated cotton leaves one day and another two days on untreated cotton leaves, while indoxacarb was the least effective $(60 \%)$ (Table $5)$. Based on the general mean of residual activity of the tested compounds, pyridalyl was superior compound giving 54\%, followed by chlorfluazuron and emamectin-benzoate (49.0 and $42.13 \%$ ), respectively. On the other hand, indoxacarb $(22.49 \%)$ was the least effective.

With regard to the aforementioned results, the efficiency of all tested compounds decreased gradually after spray. Although, indoxacarb was highly effective against $S$. littoralis larvae, laboratory strain compared to the other tested compounds, but it was low effective under field conditions thus, as criteria the efficiency of any insecticide was to be evaluated under field conditions.

Concerning the persistence of the tested compounds residues on cotton foliar under field conditions with $\mathrm{Lt}_{50}$, the results in Table (5) revealed that pyridalyl showed significant superior persistence residual activity against $4^{\text {th }}$ larval instar, field strain with $\mathrm{Lt}_{50}$ (7.74 days), emamectin-benzoate and chlorfluazuron came in the second order, with $\mathrm{Lt}_{50}$ (5.59 and 5.56 days), respectively. On the contrary, indoxacarbb showed the shortest persistence period recording 1.4 days. This may be explained by either the diversity in cotton foliage capability for adsorption of different tested insecticides into epicuticular waxes and deeper leaf tissues or the degradation factors, which act versus the persistence of insecticide residue on cotton foliage. The persistence period of insecticide residue, under the same weathering conditions, differed according to the used concentration, the sprayed plant and the target insect, when spinosad was applied against neonate of Spodoptera exigua, it had half-life of 10-20 days on Kiwi fruit foliage comparing to 7 days on cotton foliage (McDonald et al., 1998). Also, Isayama and Kasamatsu (2004) indicated that pyridalyl still demonstrates a mortality of $100 \%$ on potted cabbage plant even 14 days after treatment against Spodoptera litura even after an occurrence of rainfall immediately after application. Gupta et al. (2009) reported that the half-life time of indoxacarb at 70 and $140 \mathrm{~g} / \mathrm{ha}$ on Okra fruit was 0.58 and 1.02 days, respectively. 


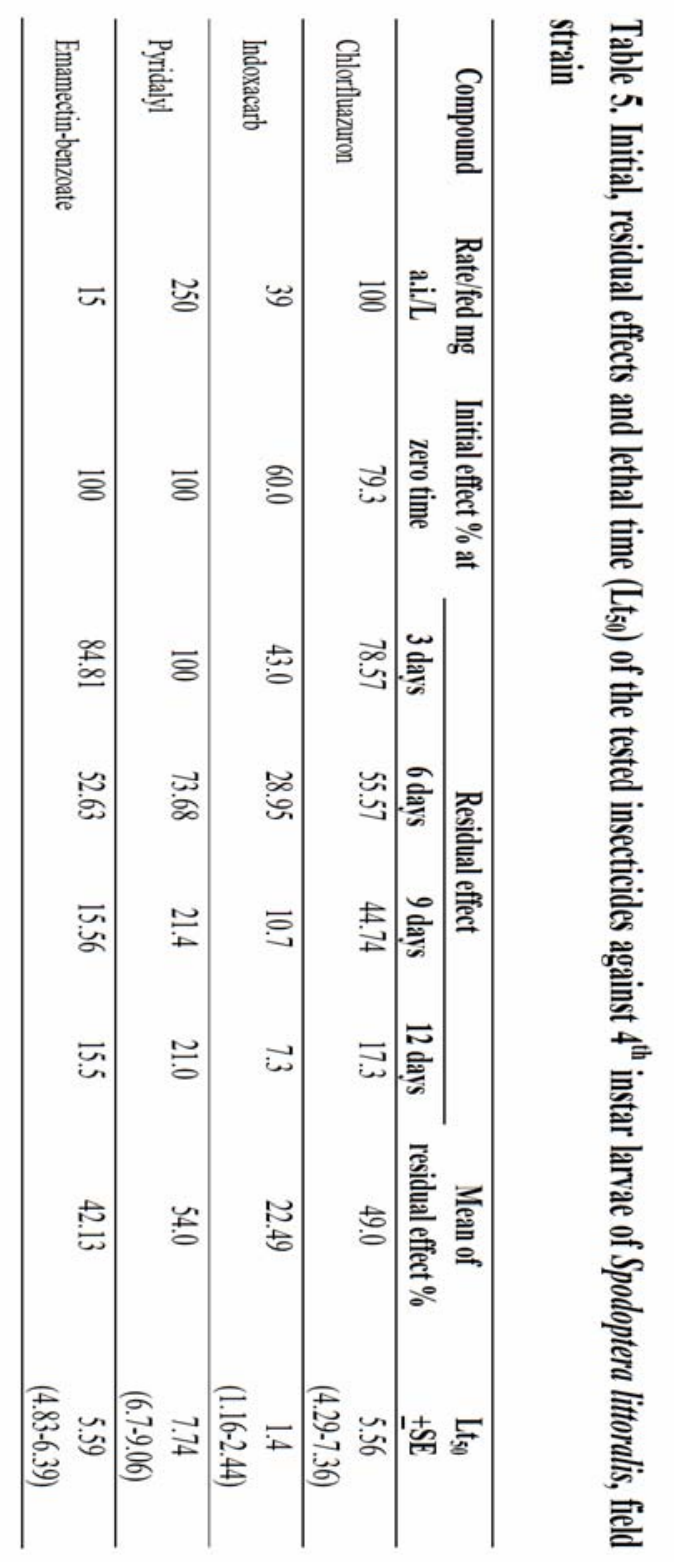




\section{CONCLUSION}

From the present results, it could be concluded that although indoxacarb highly effective against cotton leaf worm, Spodoptera littoralis (laboratory strain) and significantly reduced biological aspects, but it have the lowest effect against field strain of this pest and low initial effect, then lowest persistence period under field conditions. Pyridalyl and emamectin-benzoate caused high toxicity and significantly reduced the biological aspects against $S$. littoralis. Also these compounds had longest persistence residues and high initial effect under field conditions. Therefore, these compounds could be used in the integrated pest management (IPM) programmes, in order to minimize the negative effects of chemical insecticides on the environments and to protect the natural enemies.

\section{REFERENCES}

Abbott, M.S. (1925). A method of computing the effectiveness of an insecticide. J. Econ. Entomol., 18: 265267.

Abdel-Rahim, E.F.; A.M. Azab; M.M. Ali; G.A. Morsi and M.A. Ahmed (2009). Comparative toxicity of three noval biotic compounds, spinosad pyridalyl and radical in relative to a conventional insecticide, lannate against the field and laboratory strain of the second and fourth instar larvae of cotton leafworm, Spodoptera littoralis (Boisd.). Egypt. J. Agric. Res., 87(2): 433-452.

Abdu-Allah, G.A.M. (2010). Laboratory and field evaluation of emamectin-benzoate and spinetoram on cotton leafworm larvae. Resis. Pest Manag. Newsletter, 20(1): 13-17.

Abo El-Ghar, G.E.S.; H.S.A. Radwan; Z.A. El-Bermawy and L.T.M. Zidan (1994). Histopathological effects of abamectin, thuringiensis and diflubenzuron on the midgut of Spodoptera littoralis (Lepidoptera: Noctuidae) larvae. Bull. Ent. Soc. Egypt, 21: 41-52.

Ahmed, M.; M.A. Saleem; M. Ahmed and A.H. Sayyed (2006). Time trends in mortality for conventional and new insecticides against leafworm, Spodoptera litura, (Lepidoptera: Noctuidae). Pakistan J. Biolog. Sci., 9(3): 360-364.

Aioub, A.A.; S.A. Raslan; E.A. Gomaa; W.M. Desuky and A.A. Zaki (2002). Effectiveness of certain insect growth inhibitors on cotton leafworm. Zagazig J. Agric. Res., 29(1): 247-267.

Amer, R.A.; A.E. Hatem and A.M. Adly (2012). Effect of emamectin benzoate and pyridalyl on some demotraphic aspects of pink bollworm, Pectinophora gossypiella (Saunder). Egypt. J. Agric. Res., 90(2): 657-672.

Azab, S.G.; M.M. Sadek and K. Crailsheim (2001). Protein metabolism in larvae of the cotton leafworm, Spodoptera littoralis (Lepidoptera: Noctuidae) and its response to three mycotoxins. J. Econ. Entomol., 30: 817-823.
Burg, R.W.; B.M. Miller; E.E. Baker; J. Birgnbaum; S.A. Currie; R. Hartman; Y.L. Kong; R.L. Monaghan; G. Olson; I. Putter; J.B. Tunaca; H. Wallick; E.O. Stapley; R. Oiwa and S. Omura (1979). Avermactins a new family of potent anthelminthic agents producing organisms and fermentations. Antimicrob. Agents. Chemothe., 15: 361367.

Costat Program (2006). Version 6.311, cohort Software Inc., Monterey http: www.cohort.com/download.costat.html.

Crystal, M.M. and L.E. Lachance (1963). The modification of reproduction in insect treated with alkylating agents. Inhibition of ovarian growth and egg reproduction and hatchability. Biol. Bull., 25: 270-279.

El-Aw, M.A. (2003). Bioassays and sublethal effects of various selected insecticides on some biological aspects of the cotton leafworm Spodoptera littoralis (Boisd.) (Lepidoptera: Noctuidae). Alex. J. Agric. Res., 48(8): 7382.

El-Deeb, M.A.; F.E. Ghouneim and F.I. Helmy (1991). Potential use of the juvenile hormone pyriproxyfen for the control of Spodoptera littoralis. $4^{\text {th }}$ Arab Cong. Plant Protect. Cairo, Egypt, 7-13.

El-Defrawi, M.E.; A. Toppozada; N. Mansour and M. Zeid (1964). Toxicological studies on the Egyptian cotton leafworm Prodenia litura. I. Susceptibility of different larval instars of prodenia to insecticides. J. Econ. Entomol. 57: 591-593.

El-Naggar, J.B.A. (2013). Sublethal effects of certain insecticides on biological and physiological aspects of Spodoptera littoralis (Boisd.). Nature and Science, 11(17): 19-25.

El-Naggar, J.B.A. and M.E.H. El-Dewy (2012). Efficiency of certain insecticides on biological aspects of Spodoptera littoralis (Boisd.). Egypt. J. Agric. Res., 90(2): 387-398.

El-Zahi, E.S. (2013). Field persistence of some noval insecticides residues on cotton plants and their latent effects against Spodoptera littoralis (Boisduval). Alex. Sci. Exch. J. 34(1): 37-43.

Emam, A. and D. Degheele (1993). Ovicidal activity of benzoylphenyl ureas applied alone or together with Atplus $411 \mathrm{f}$ on Spodoptera littoralis (Boisd.). Mededlingen van de facultei L Landbouwetenschappen, Universiteit Gent., 58(28): 677-683.

Ezz El-Din, H.A.; A.M. El-Ghareeb; A.M.K. El-Sayed and G.A.M. Abdu-Allah (2009). Toxicity of spinosad and abamectin compared with some conventional insecticides against parent field strain of cotton leafworm, Spodoptera littoralis (Boisd.). J. Agric. Sci. Mansoura Univ., 34: 5221-5229.

Finney, D.J. (1971). Probit Analysis. $3^{\text {rd }}$ ed. Cambridge Univ. Press, London, $318 \mathrm{p}$.

Fisk, T. and D.J. Wright (1992). Speed of action and toxicity of acylurea insect growth regulators against, Spodoptera exempta (Walk.) and Spodoptera littoralis (Boisd.) larvae, effect of intermoulting. Pestic. Sci., 35(4): 331-337. 
Foster, S.P.; I. Denholm and R. Thompson (2003). Variation in response to Neonictinoid insecticides in peach-potato aphids. Myzus persicae (Homoptera: Aphididae). Pest Manag. Sci., 59(2): 166-173.

Frank, R.; H.E. Broun; B.D. Ripley and B.S. Clegy (1990). Contamination or rural ponds with pesticides, 1971-1985. Ontario, Canada. Bull. Environ. Contamin. Toxicol., 13: 771-817.

Fritz, L.C.; C.C. Wang and A. Gorio (1979). Avermectin Bla irreversibly block post synaptic potentials of the lobster neuromuscular junction by reducing muscle membrane resistance. Proc. Nat. Acad. Sci., USA, 76: 2062-2066.

Gupta, S.; R.K. Sharma and R.K. Gupta (2009). Persistence of new insecticides and their efficacy against insect pests of okra. Bull. Environ. Contam. Toxicol., 82: 243-247.

Isayama, S. and K. Kasamatsu (2004). Abstracts of papers, $49^{\text {th }}$ Annual Meeting of Japanese Society of Applied Entomology and Zoology, Tokyo, 92.

Isayama, S.; S. Saito; K. Kuroda; K. Umeda and K. Aama (2005). Pyridalyl a novel insecticide potency and insecticidal selectivity. Arch. Insect. Biochem. Physiol., 58(4): 226-330.

Lasota, J.A. and R.A. Dybas, (1991). Avermectins, a noval class of compounds : implications for use in arthropod pest control. Annu. Rev. Entomol., 36: 91-117.

McDonald, P.t.; M.K. Kish; P.A. King; F.J. Dunagan and R.T. Weiland (1998). Field persistence of several insecticides on cotton foliage as determined by beet armyworm Spodoptera exigua Bioassay. Proceedings Beltwide Cotton Conf., 2: 1164-1166.

Michaud, J.P. and A.K. Grant (2003). IPM-compatibility of foliar insecticides for citrus: indices derived from toxicity to beneficial insects from four orders. J. Insect. Sci., 3: 110.

Mrotzit, H. (1994). Advances in research and development of Avermectin. An. Chem. Soc. Symo. Ser., 551: 54-73.

Nicholas, A.H.; W.G. Thwaite and R.N. Spooner-Hart (1999). Arthropod in an Australian apple orchard under mating disruption and supplementary abundance insecticide treatments for codling moth. Cydia pomonella (L.) (Lepidoptera: Torticidae). Austral. J. Entomol., 38: 23-29.

Pienkowski, R.L. and P.R. Mehring (1983). Influence of avermactin B1 and carbofuran on feeding by alfalfa weevil larvae (Coleoptera: Curculionidae). J. Econ. Entomol., 76: 1167-1169.

Pineda, S.; M.I. Schneider; G. Smagghe; A.M. Martinez; P. Delestal; E. Vinuela; J. Valel and F. Budia (2007). Lethal and sublethal effects of methoxyfenozide and spinosad on Spodoptera littoralis (Lepidoptera: Noctuidae). J. Econ. Entomol., 100(3): 773-780.
Rao, N.V.; K. Rao and A.S. Redy (1994). A note on the efficacy of IGR to caterpillar, Helicoverpa armigera (Hub.) J. Insect. Sci., 5: 169-171.

Saito, S.; S. Isayama; N. Sakamoto and K. Umeda (2004). Insecticidal activity of pyridalyl acute and sub-acute symptoms in Spodoptera litura larvae. J. Pestic. Sci. 29: 372-375.

Sakamoto, N. and K. Umeda (2003). Fine Chemicals, 32(2): $35-44$.

Sakamoto, N.; N. Ueda, N.; K. Umeda; S. Matsuot; T. Hagat; T. Fujisawa and Y. Tomigahara (2005). Research and development of a noval insecticide "pyridalyl", "Sumitomo Kagaku" Chem. Abst., 1: 133-144.

Sakamoto, N.; S. Matsuo; M. Suzuki; T. Hirose; K. Tsushima and W.O. Umeda (1995). Patent 9611909, Chem. Abst. $1995,125,114466$.

Sammour, E.A.; M.A. Kandil and N.F. Abdel-Aziz (2008). The reproductive potential and fate of chlorfluzuron and lufenuron against cotton leafworm, Spodoptera littoralis (Boisd.) Am. Euro. J. Agric. \& Environ. Sci. 4(1): 62-67.

Shaurub, E.H.; Z.A. Ahmed and E.M. Samica (1998). Impacts of pyriproxyfen and extracts of Schinus terebinthifolius on development reproduction and reproductive organs in Spodoptera littoralis. J. Egypt. Ger. Soc. Zool. (E): 57-82.

Smagghe, G. and D. Degheele (1997). Comparative toxicity and tolerance for the ecdysteroid mimic tebufenozide in a laboratory strain of cotton leafworm (Lepidoptera: Noctuidae). J. Econ. Entomol., 90: 278-282

SPSS (2004). SPSS 13.0 for windows, SPSS Inc., Chicago.

Tabashink, B.E.; N.L. Cushing and M.W. Johnson (1987). Diamond back moth (Lepidoptera: Putellidae) resistance to insecticides in Hawaii: intraisland variation and cross resistance. J. Econ. Entomol., 80: 1091-1099.

White, S.; D.M. Dunbar; R. Brown; B. Cartwright; D. Cox; C. Eckel; R.K. Jansson; P.K. Mookerge; J.A. Norton; R.F. Peterson and V.R. Starnet (1997). Emamectin-benzoate: a noval avermectin derivative for control of lepidopterous pests in cotton. Proceedings of Beltwide Cotton Conf., 1078-1082.

Writht, J.E. (1984). Biological activity of AMERVECTIN B1 against the boll weevil (Coleoptera: Curculionidae). J. Econ. Entomol., 77: 1029-1030.

Zidan, L.t.; M.H. Rashwan and M.A. Abd El-Razik (2013). Comparative curative and preventive ovicidall effectiveness of certain selected IGRs and insecticides against the cotton leafworm and sweetpotato. New York. Sci. J., 6(12): 83-91. 


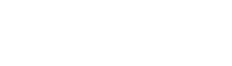

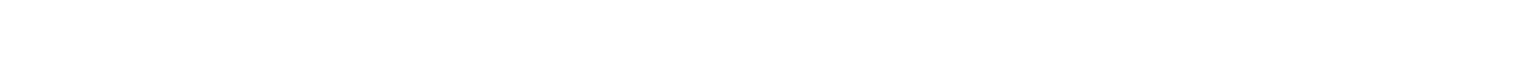

\section{وق النلن}

مدله الصباحى حلمد الديوى

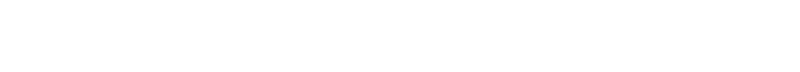

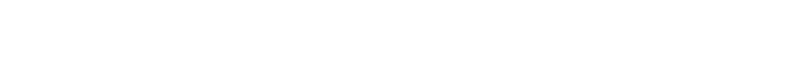

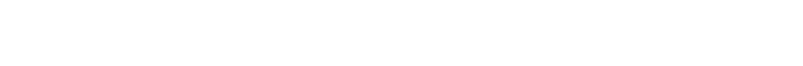

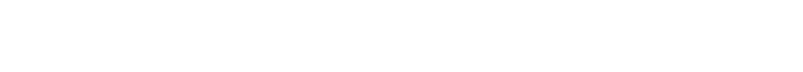

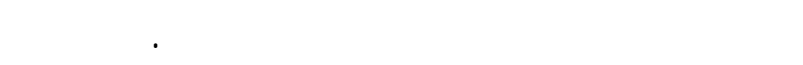

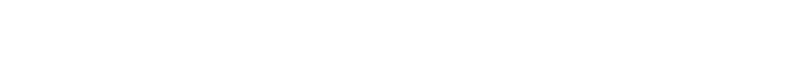
ظل الظروف المقلية بنغذية يرقت العمر الراع للسلالة الهتلية على

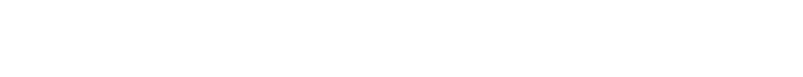

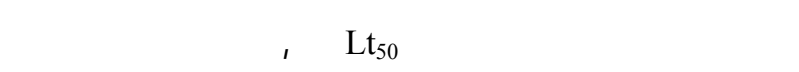

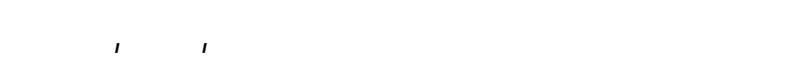

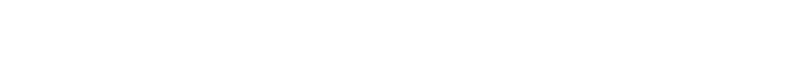

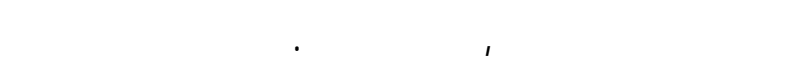

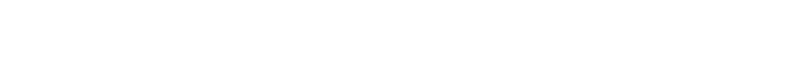

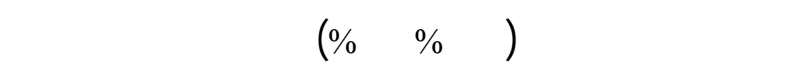

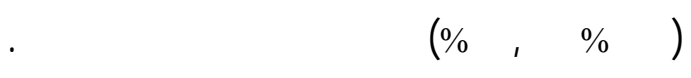

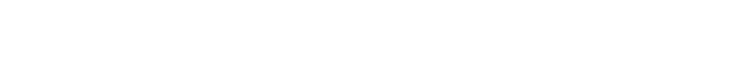

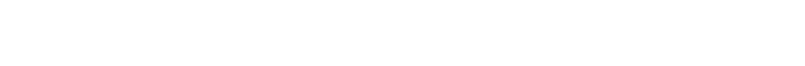

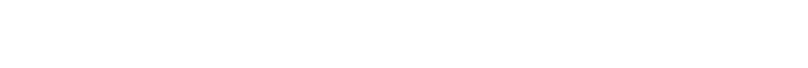

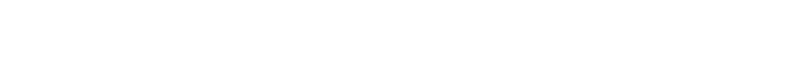

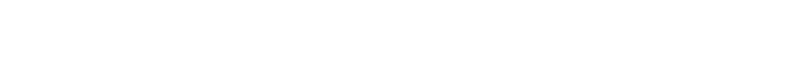

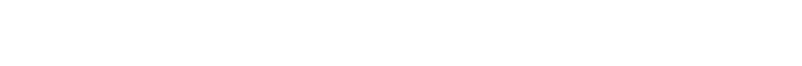

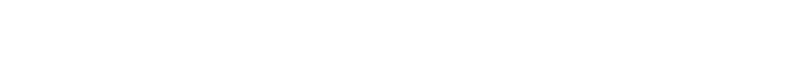

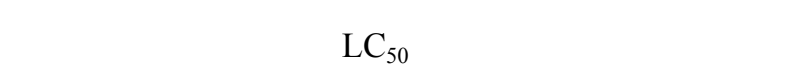

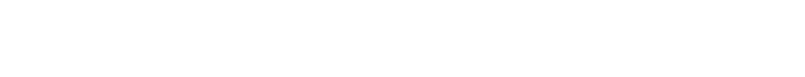

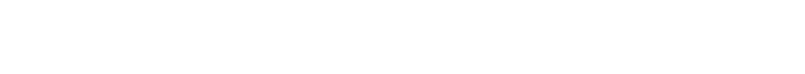

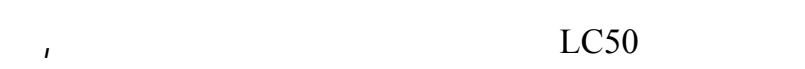

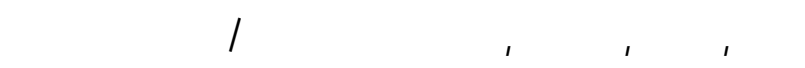

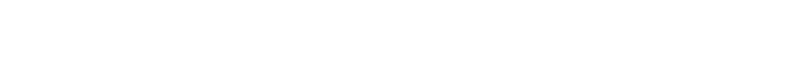
TIT

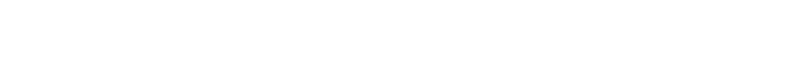

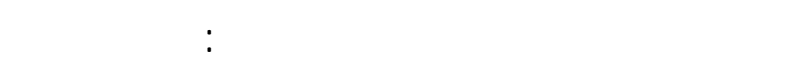

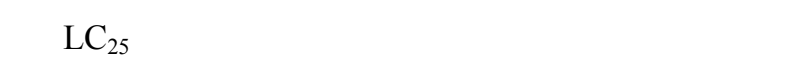

